УДК 519.816

Хомчак Р. Б.

Міністерство оборони України, Київ

\title{
Аналіз методичного апарату для порівняльного оцінювання бойової могутності збройних сил різних країн світу та напрями його подальшого розвитку
}

Резюме. У статті проведено аналіз сучасного методичного апарату для порівняльного оцінювання бойової могутності збройних сил різних країн світу з використанням факторного аналізу та визначено напрями його подальшого розвитку.

Ключові слова: порівняльне оцінювання, факторний аналіз, рейтинг збройних сил, бойова потужності збройних сил.

Постановка проблеми. На сучасному етапі розвитку Збройних Сил України одним 3 пріоритетних завдань $€$ підвищення їх спроможностей щодо відбиття можливої агресії. Однак ця проблема $є$ характерною не лише для України, а й для інших країн, які не входять до жодного 3 військово-політичних блоків. Фактично збройні сили (3С) таких країн мають бути готові до відбиття агресії 3 будь-якого можливого напрямку.

В основу прийняття рішень, які повинні забезпечити розв'язання цієї проблеми, мають покладатися результати аналізу якомога більшої кількості факторів, які визначають необхідний рівень обороноздатності держави. Цілком очевидно, що такий аналіз важливо провести, насамперед, стосовно співвідношення бойової могутності можливих протидіючих сторін на визначених загрозливих напрямках, у першу чергу, їх 3С. При цьому пролонгація такого аналізу на певну перспективу становитиме вагоме підгрунтя як для обгрунтування потрібного складу Збройних Сил України, так і для уточнення змісту інших заходів, спрямованих на підвищення обороноздатності нашої держави.

Таким чином, удосконалення методичного апарату для порівняльного оцінювання бойової могутності $3 \mathrm{C}$ різних країн світу $\epsilon$ актуальним напрямом досліджень.

Аналіз останніх досліджень i публікацій. Як відомо [1], бойова могутність 3С - це складова бойової могутності держави, сукупність матеріальних та духовних факторів, які визначають стан 3С та їх оперативні спроможності виконувати бойові завдання. Бойова могутність залежить від чисельного та якісного складу ЗС, їх укомплектованості та технічного оснащення, рівня підготовки, боєготовності та боєздатності військ (сил), рівня військового мистецтва тощо. Бойова могутність ЗС прямо або опосередковано залежить від економічної могутності, політики, воєнної доктрини держави.

3 аналізу наведеного визначення випливає, що оцінювання бойової могутності держави є досить складним завданням через необхідність врахування великої кількості чинників.

При цьому врахування значної частини 3 них, наприклад, духовного фактору, рівня військового мистецтва тощо, пов'язане зі значними труднощами, які мають подвійну природу. 3 одного боку ці фактори є якісними, тобто для їх формалізованого аналізу необхідно вводити деякі додаткові шкали для забезпечення можливості надання імм кількісних значень. 3 іншого - отримання достовірних даних стосовно більшості 3 таких факторів (наприклад, рівня підготовки, боєготовності та боєздатності тощо) для різних країн $\epsilon$ неможливим внаслідок відсутності відповідної інформації у відкритих джерелах.

Виходячи 3 того, що найбільш доступними для аналізу $\epsilon$ характеристики економічного розвитку країн та чисельного складу їх 3С, сучасний методичний апарат для порівняльного оцінювання бойової могутності 3С різних країн світу фактично використовує два підходи. В першому з них здійснюється порівняння бойової могутності ЗС на основі аналізу їх чисельності (за особовим складом та оснащеністю зразками озброєння). У другому підході, враховуючи залежність бойової могутності ЗС від рівня економічного розвитку країни, додатково враховуються показники, які пов'язані 3 економікою країни та характеризують їі.

Прикладом першого підходу $\epsilon$ 
дослідження Swiss multinational financial services holding company [2], у якому здійснюється порівняння бойової могутності ЗС двадцяти країн світу за шістьма показниками: чисельністю особового складу, кількістю танків, літаків, ударних вертольотів, авіаносців та підводних човнів. При цьому кожному 3 показників надається ваговий коефіцієнт: особовому складу - 0,05 ; танкам --
0,10 ; літакам - 0,20; ударним вертольотах - 0,15; авіаносцям - 0,25; підводним човнам - 0,25.

Американський журнал Business Insider [3] здійснюе порівняння ЗС країн світу 3 використанням семи показників: чисельність 3С, кількість танків, літаків, ядерних боєголовок, авіаносців, підводних човнів та загальний воєнний бюджет (див. табл. 1).

Рейтинг збройних сил різних країн світу за версією журналу Business Insider (2014 рік)

\begin{tabular}{|c|c|c|c|c|c|c|c|c|}
\hline 营 & & 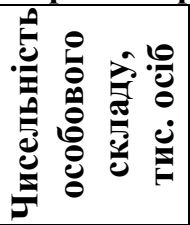 & 先 & $\underset{5}{5}$ & 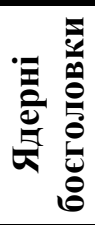 & 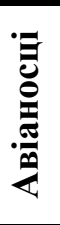 & 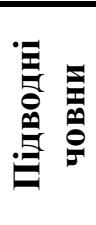 & 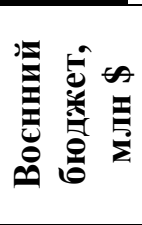 \\
\hline $\mathbf{1}$ & CIIA & 1430 & 8325 & 13683 & 7506 & 10 & 72 & 612500 \\
\hline 2 & Російська Федерація & 766 & 15000 & 3082 & 8484 & 1 & 63 & 76600 \\
\hline 3 & Китай & 2285 & 9150 & 2788 & 250 & 1 & 69 & 126000 \\
\hline 4 & Індія & 1325 & 3569 & 1785 & 90 & 2 & 17 & 46000 \\
\hline 5 & Велика Британія & 205,33 & 407 & 908 & 225 & 1 & 11 & 53600 \\
\hline 6 & Франція & 228,656 & 423 & 1203 & 300 & 1 & 10 & 43000 \\
\hline 7 & Германія & 183 & 408 & 710 & 0 & 0 & 4 & 45000 \\
\hline 8 & Туреччина & 410,5 & 3657 & 989 & 0 & 0 & 14 & 18185 \\
\hline 9 & Південна Корея & 640 & 2346 & 1393 & 0 & 0 & 14 & 33700 \\
\hline 10 & Японія & 247.746 & 767 & 1595 & 0 & 1 & 16 & 49100 \\
\hline 11 & Ізраїль & 176,5 & 3870 & 680 & 140 & 0 & 14 & 15000 \\
\hline 12 & Італія & 320 & 600 & 795 & 0 & 2 & 6 & 34000 \\
\hline 13 & Єгипет & 468.5 & 4767 & 1100 & 0 & 0 & 4 & 4400 \\
\hline 14 & Бразилія & 328 & 489 & 748 & 0 & 1 & 5 & 33142 \\
\hline 15 & Пакистан & 617 & 3124 & 847 & 100 & 0 & 8 & 7000 \\
\hline 16 & Канада & 68,25 & 201 & 404 & 0 & 0 & 4 & 18000 \\
\hline 17 & Тайвань & 290 & 2005 & 775 & 0 & 0 & 4 & 10725 \\
\hline 18 & Польща & 120 & 1063 & 475 & 0 & 0 & 5 & 9360 \\
\hline 19 & Індонезія & 476 & 374 & 381 & 0 & 0 & 2 & 6900 \\
\hline 20 & Австралія & 58 & 59 & 385 & 0 & 0 & 6 & 26100 \\
\hline 21 & Україна & 160 & 4112 & 400 & 0 & 0 & 1 & 4880 \\
\hline 22 & Іран & 545 & 2409 & 481 & 0 & 0 & 31 & 6300 \\
\hline 23 & В'єтнам & 412 & 3200 & 413 & 0 & 0 & 1 & 3365 \\
\hline 24 & Таїланд & 306 & 740 & 543 & 0 & 1 & 0 & 5390 \\
\hline 25 & Саудівська Аравія & 233,5 & 1095 & 652 & 0 & 0 & 0 & 56725 \\
\hline 26 & Сирія & 178 & 4950 & 473 & 0 & 0 & 0 & 1872 \\
\hline 27 & Швейцарія & 135 & 200 & 175 & 0 & 0 & 0 & 4830 \\
\hline 28 & Іспанія & 123,3 & 415 & 531 & 0 & 1 & 3 & 11600 \\
\hline 29 & Швеція & 14 & 280 & 216 & 0 & 0 & 5 & 6215 \\
\hline 30 & Чехія & 21,06 & 123 & 109 & 0 & 0 & 0 & 2220 \\
\hline 31 & Алжир & 512 & 1050 & 404 & 0 & 0 & 6 & 10570 \\
\hline 32 & Нідерланди & 47,66 & 0 & 160 & 0 & 0 & 4 & 9840 \\
\hline 33 & Мексика & 267,5 & 0 & 373 & 0 & 0 & 0 & 7000 \\
\hline 34 & Бельгія & 33 & 52 & 166 & 0 & 0 & 0 & 5085 \\
\hline 35 & Північна Корея & 690 & 6600 & 943 & 10 & 0 & 78 & 7500 \\
\hline
\end{tabular}


Найбільш авторитетним у світі вважається рейтинг бойової могутності ЗС країн світу, який складається за даними 3 відкритих джерел компанією Global Firepower [4].

Порівняння бойової могутності здійснюється експертами за значною кількістю показників (табл. 2), виходячи 3 таких міркувань:

враховується лише звичайне озброєння, однак країни, які мають ядерну зброю, отримують деяку додаткову кількість балів;

враховується не стільки кількість озброєння, скільки його різноманіття та якість; на бойову потужність впливають географічні характеристики країни, iï інфраструктура та природні ресурси;

враховується кількість населення та доступні трудові ресурси; країни;

країни, які не мають виходу до моря, не отримують штрафних балів за відсутність флоту, однак країни 3 малим різноманіттям морських озброєнь отримують штрафні бали;

країни-члени НАТО отримують додаткові бали за рахунок спільного використання ресурсів;

характер та особливості поточного воєнно-політичного керівництва країною не враховується.

Таблиця 2

Перелік показників, за якими здійснюється визначення бойової потужності збройних сил різних країн за методикою Global Firepower

\begin{tabular}{|c|c|c|c|}
\hline № & Назва показника & № & Назва показника \\
\hline 1 & Загальний ранг бойової могутності & 24 & Кількість есмінців \\
\hline 2 & Індекс могутності & 25 & Кількість корветів \\
\hline 3 & Усього населення & 26 & Кількість підводних човнів \\
\hline 4 & Доступна робоча сила & 27 & Кількість літаків берегового патруля \\
\hline 5 & Кількість осіб, придатних до служби & 28 & Кількість міноносців \\
\hline 6 & Кількість осіб, які щорічно досягають призовного віку & 29 & Виробництво нафти \\
\hline 7 & Численність збройних сил & 30 & Споживання нафти \\
\hline 8 & Мобілізаційний резерв & 31 & Достовірні розвідані запаси нафти \\
\hline 9 & Кількість танків & 32 & Усього робочої сили \\
\hline 10 & Кількість броньованих машин & 33 & Чисельність торгівельного флоту \\
\hline 11 & Кількість самохідної артилерії & 34 & Кількість основних портів та терміналів \\
\hline 12 & Кількість буксованих артилерійські систем & 35 & Покриття автомобільними дорогами \\
\hline 13 & Кількість ракетних систем (РСЗВ) & 36 & Покриття залізними дорогами \\
\hline 14 & Усього літаків & 37 & Кількість функціонуючих аеропортів \\
\hline 15 & Кількість винищувачів / перехоплювачів & 38 & Військовий бюджет \\
\hline 16 & Кількість ударних літаків з незмінним крилом & 39 & Зовнішній борг \\
\hline 17 & Кількість транспортних літаків & 40 & Золотовалютні резерви \\
\hline 18 & Кількість тренувальних літаків & 41 & Паритет купівельної спроможності \\
\hline 19 & Кількість вертольотів & 42 & Площа країни \\
\hline 20 & Кількість ударних вертольотів & 43 & Довжина берегової лінії \\
\hline 21 & Загальна чисельність військово-морських сил & 44 & Довжина границь з іншими країнами \\
\hline 22 & Кількість авіаносців & 45 & Покриття водними шляхами \\
\hline 23 & Кількість фрегатів & & \\
\hline
\end{tabular}

За кожним з показників ЗС відповідної країни призначається деякий бал (коефіцієнт), а за аналізом усієї сукупності балів (коефіцієнтів) створюється рейтингова таблиця.

У результаті такого порівняння ЗС деякої країни отримують індекс могутності (Power index), який характеризує їх бойову могутність порівняно із 3 С інших країн. Цей індекс $\epsilon$ десятковим дробом 3 чотирма знаками після коми. Вважається, що ідеальна армія має значення індексу 0,0000 .

Ранг 3С за бойовою могутністю визначається за результатами впорядкування країн за зростанням індексу могутності.

Значення показників, наведених у табл. 2 (у тому числі і результати рейтингування), для 133-х країн світу з 2011 року доступні на сайті https://knoema.com/. Однак за різні роки перелік країн та перелік показників, для яких $\epsilon$ 
відповідні числові значення, дещо різняться.

Надаючи загальну оцінку розглянутому методичному апарату для порівняльного оцінювання бойової могутності ЗС різних країн світу, необхідно зазначити, що фактично для наукової спільноти доступними є лише результати порівняльного аналізу. Використовувані для розрахунків методики (методичні підходи) у формалізованому вигляді не надаються, що не дає змоги оцінити особливості проведеного порівняння та оцінити його достовірність.

Однак надати опосередковану характеристику цьому методичному апарату можна шляхом аналізу отримуваних за ним результатів, що i буде підставою для визначення шляхів його подальшого розвитку.

Метою статті $\epsilon$ висвітлення особливостей існуючого методичного апарату для порівняльного оцінювання бойової могутності збройних сил різних країн світу, розгляд отриманих результатів та визначення напрямів його удосконалення.

Виклад основного матеріалу. В основу аналізу результатів, отримуваних із використанням сучасного методичного апарату для порівняльного оцінювання бойової могутності 3С різних країн світу, покладемо метод факторного аналізу, який дає змогу викривати латентні зв'язки між значеннями розглядуваних показників.

При цьому будемо виходити 3 гіпотези, що незалежно від використаного методичного підходу, отримані за ними результати повинні мати наочну змістовну інтерпретацію, а також не повинні суперечити наявним поглядам на застосування збройних сил.

Апарат факторного аналізу достатньо повно викладено в спеціальній літературі, наприклад, [5, 6]. Додатково зазначимо, що відповідно до [7], результати факторного аналізу вважаються прийнятними, якщо виділені фактори дають змогу пояснити не менше за $75 \%$ змінюваності дисперсій розглядуваних змінних. При цьому фактор пов'язується зі змінною, якщо факторне навантаження на неї перевищує 0,7 , а факторні навантаження, які є меншими за 0,43 , можна вважати несуттєвими.

Аналіз результатів використання сучасного методичного апарату для порівняльного оцінювання бойової могутності 3С різних країн світу проведемо на двох прикладах.

В якості вихідних даних для першого прикладу скористаємося даними, наведеними в табл. 1, що надасть підстави оцінити методичні підходи, які використовуються в журналі Business Insider.

Факторні навантаження повернутої матриці факторів, що отримані для даних, наведених у табл. 1, наведено в табл. 3. При цьому частка поясненої дисперсії змінних для двох виділених факторів становить 0,7988, тобто $€$ достатньою для отримання обгрунтованих висновків.

Таблиця 3

Факторні навантаження повернутої матриці факторів, отримані для даних Прикладу 1

\begin{tabular}{|l|c|c|}
\hline \multicolumn{1}{|c|}{ Назва показника } & \multicolumn{2}{c|}{ Факторні навантаження від } \\
\cline { 2 - 3 } & фактора 1 & фактора 2 \\
\hline Рейтинг & $-0,36$ & 0,50 \\
\hline Чисельність збройних сил & 0,00 & $-0,80$ \\
\hline Кількість танків & 0,00 & -0.92 \\
\hline Кількість літаків & 0,91 & 0,00 \\
\hline Кількість ядерних босголовок & 0,63 & $-0,54$ \\
\hline Кількість авіаносців & 0,96 & 0,00 \\
\hline Кількість підводних човнів & 0,00 & $-0,84$ \\
\hline Загальний воснний бюджет & 0,94 & 0,00 \\
\hline
\end{tabular}

Аналіз даних, наведених у табл. 3, свідчить, що перший фактор пов'язаний зі зразками озброєння, придбання та утримання яких потребує найбільших видатків iз загального воєнного бюджету та значною мірою визначає його величину (кількість літаків та авіаносців). Фактично перший фактор можна асоціювати 3 повітряною компонентою 3С. При цьому рівень бойової могутності, який визначається рейтингом армії деякої країни в пріоритетному ряді, 3 цим фактором практично пов'язаний досить слабко, адже його значення 0,36 - менше за гранично рекомендоване для врахування.

Другий фактор забезпечує найбільше навантаження на кількість танків, підводних човнів та чисельність 3С, тобто може бути асоційований 3 іншими показниками. При цьому навантаження від другого фактора на рівень бойової могутності $\epsilon$ достатнім для необхідності його врахування, однак його величина свідчить про слабкий вплив цих 
складових ЗС на оцінку рівня їх бойової могутності.

Зв'язок кількості ядерних боєголовок 3 кожним із факторів $є$ сумарним.

Проведений аналіз проказав, що оцінка бойової могутності за підходом, використаним у [3], слабко залежить від авіаційної компоненти 3С, хоча загальновідомо, що в більшості випадків за відсутності авіації (або в разі недостатньої іiі кількості) збройні сили виконати поставлені завдання практично неспроможні. Окрім того, виявлено слабкий зв'язок оцінки бойової могутності 3 іншими показниками.

Проведений аналіз свідчить, що підхід, використаний у [3] для порівняльного оцінювання бойової могутності ЗС різних країн, не дозволяе надати зрозумілого пояснення результатам ранжування, що наведені у табл. 1.

Вихідними даними для другого прикладу $\epsilon$ значення показників, за якими здійснювалось визначення індексу могутності 3С різних країн світу в 2015 році за методикою Global Firepower (наведено на сайті https://knoema.com/). Це надасть підстави оцінити методику, використовувану компанією Global Firepower.

Вибір даних за 2015 рік пояснюється тим, що для нього $є$ доступними значення всіх показників, наведених у табл. 2 для 99-ти країн, тобто забезпечується достатній обсяг статистичних матеріалів для формування достовірних висновків за результатами проведеного аналізу.

Факторні навантаження повернутої матриці факторів для цих даних наведено в табл. 4 (факторні навантаження, які більші за 0,95 заокруглено до 1). При цьому частка поясненої дисперсії змінних для шести виділених факторів становить 0,875 , тобто $\epsilon$ достатньою для отримання обгрунтованих висновків.

Аналіз даних, наведених у табл. 4, свідчить, що перший фактор може бути асоційований $з$ авіаційною компонентою ЗС, другий - 3 людськими ресурсами, необхідними для комплектування армії, третій - з обороною території, четвертий - 3 охороною узбережжя, п'ятий - 3 результатами рейтингування армій за бойовою могутністю за наявності слабкого зв'язку з оснащеністю морського узбережжя портами та терміналами, шостий - із запасами нафти.

Принциповим результатом факторного аналізу для Прикладу 2 є те, що результати рейтингування армій за бойовою могутністю виділились в окремий фактор, який фактично не пов'язаний 3 іншими показниками, використаними для розрахунків.

Виникає парадоксальна ситуація, коли результати оцінювання бойової могутності фактично не пов' язані $з$ жодним із показників, які були використані як вихідні дані. Логічним було б очікувати, що індекс могутності мав би деякі, нехай незначні, факторні навантаження від усіх факторів, а наслідком їх кумулятивного ефекту були б відповідні значення індексу могутності. Однак розрахунки показали зовсім інші результати.

Таким чином, аналіз методичного апарату для порівняльного оцінювання бойової могутності 3С країн світу свідчить, що йому притаманна низка недоліків.

1. Для порівняння бойової могутності 3С різних країн дослідники використовують різні методичні підходи та різну сукупність показників, які характеризують бойову могутність, що має наслідком несумірність отримуваних рівнів бойової могутності й те, що збройні сили однієї країни в різних рейтингах бойової могутності посідають різні місця.

2. Формалізований опис відповідного методичного апарату фактично відсутній. Відомо лише, що порівняння здійснювалось із залученням експертів, які на основі аналізу множини розглядуваних показників надавали перевагу 3С тієї чи іншої країни. Це унеможливлює змістовний аналіз отриманих результатів.

3. Порівняння бойової могутності $3 \mathrm{C}$ різних країн здійснюється безвідносно до їх завдань. Збройні сили всіх країн розглядаються в межах однієї групи, хоча зрозуміло, що для отримання корисної інформації щодо можливих напрямів та шляхів розвитку ЗС України доцільно поділити армії країн світу на однорідні групи (кластери) за певними ознаками, в межах яких i здійснювати порівняння їх бойової могутності 3 урахуванням чинників, за рахунок яких вони мають перевагу стосовно Збройних Сил України.

4. Вплив на бойову могутність $3 \mathrm{C}$ зразків озброєння, якими вони оснащені, здійснюється лише за кількісними показниками без урахування їх реальних бойових можливостей.

5. Під час порівняння не враховуються наземні засоби протиповітряної оборони.

6. Досить складно пояснити зв'язок між показником, за яким оцінюється рівень бойової могутності 3С, 3 показниками, які були використані як вихідні дані. У обох розглянутих варіантах рейтингування ЗС за 
могутністю рейтинг фактично визначається обмеженою групою чинників, віднести які до визначальних стосовно бойової могутності, досить складно. У першому випадку - це кількість особового складу, танків та підводних човнів, а в іншому - оснащеність морського узбережжя портами та терміналами.

Таблиця 4

Факторні навантаження повернутої матриці факторів, отримані для даних Прикладу 2

\begin{tabular}{|c|c|c|c|c|c|c|}
\hline \multirow{2}{*}{$\begin{array}{c}\text { Номер } \\
\text { показника } \\
\text { з табл. } 2\end{array}$} & \multicolumn{6}{|c|}{ Факторні навантаження від } \\
\hline & фактора 1 & фактора 2 & фактора 3 & фактора 4 & фактора 5 & фактора 6 \\
\hline 1 & 0.00 & 0.00 & 0.00 & 0.00 & -0.81 & 0.00 \\
\hline 2 & 0.00 & 0.00 & 0.00 & 0.00 & -0.80 & 0.00 \\
\hline 3 & 0.00 & 0.94 & 0.00 & 0.00 & 0.00 & 0.00 \\
\hline 4 & 0.00 & 1 & 0.00 & 0.00 & 0.00 & 0.00 \\
\hline 5 & 0.00 & 1 & 0.00 & 0.00 & 0.00 & 0.00 \\
\hline 6 & 0.00 & 0.92 & 0.00 & 0.00 & 0.00 & 0.00 \\
\hline 7 & 0.00 & 0.72 & 0.00 & 0.00 & 0.00 & 0.00 \\
\hline 8 & 0.00 & 0.00 & 0.43 & -0.60 & 0.00 & 0.00 \\
\hline 9 & 0.00 & 0.00 & 0.75 & 0.00 & 0.00 & 0.00 \\
\hline 10 & -0.76 & 0.00 & 0.53 & 0.00 & 0.00 & 0.00 \\
\hline 11 & 0.00 & 0.00 & 0.89 & 0.00 & 0.00 & 0.00 \\
\hline 12 & 0.00 & 0.58 & 0.47 & -0.51 & 0.00 & 0.00 \\
\hline 13 & 0.00 & 0.00 & 0.79 & -0.45 & 0.00 & 0.00 \\
\hline 14 & -1 & 0.00 & 0.00 & 0.00 & 0.00 & 0.00 \\
\hline 15 & -0.83 & 0.00 & 0.00 & 0.00 & 0.00 & 0.00 \\
\hline 16 & -0.80 & 0.00 & 0.00 & 0.00 & 0.00 & 0.00 \\
\hline 17 & -1 & 0.00 & 0.00 & 0.00 & 0.00 & 0.00 \\
\hline 18 & -1 & 0.00 & 0.00 & 0.00 & 0.00 & 0.00 \\
\hline 19 & -1 & 0.00 & 0.00 & 0.00 & 0.00 & 0.00 \\
\hline 20 & -0.89 & 0.00 & 0.00 & 0.00 & 0.00 & 0.00 \\
\hline 21 & 0.00 & 0.00 & 0.00 & -0.66 & 0.00 & 0.00 \\
\hline 22 & -1 & 0.00 & 0.00 & 0.00 & 0.00 & 0.00 \\
\hline 23 & 0.00 & 0.67 & 0.00 & 0.00 & 0.53 & 0.00 \\
\hline 24 & -0.81 & 0.00 & 0.00 & 0.00 & 0.00 & 0.00 \\
\hline 25 & 0.00 & 0.00 & 0.86 & 0.00 & 0.00 & 0.00 \\
\hline 26 & -0.55 & 0.00 & 0.50 & 0.00 & 0.00 & 0.00 \\
\hline 27 & 0.00 & 0.00 & 0.00 & -0.84 & 0.00 & 0.00 \\
\hline 28 & 0.00 & 0.00 & 0.61 & 0.00 & 0.52 & 0.00 \\
\hline 29 & -0.45 & 0.00 & 0.44 & 0.00 & 0.00 & 0.66 \\
\hline 30 & -0.86 & 0.00 & 0.00 & 0.00 & 0.00 & 0.00 \\
\hline 31 & 0.00 & 0.00 & 0.00 & 0.00 & 0.00 & 0.87 \\
\hline 32 & 0.00 & 1 & 0.00 & 0.00 & 0.00 & 0.00 \\
\hline 33 & 0.00 & 0.48 & 0.00 & 0.00 & 0.46 & 0.00 \\
\hline 34 & -0.54 & 0.00 & 0.00 & 0.00 & 0.61 & 0.00 \\
\hline 35 & -0.80 & 0.54 & 0.00 & 0.00 & 0.00 & 0.00 \\
\hline 36 & -0.86 & 0.00 & 0.00 & 0.00 & 0.00 & 0.00 \\
\hline 37 & -0.93 & 0.00 & 0.00 & 0.00 & 0.00 & 0.00 \\
\hline 38 & -1 & 0.00 & 0.00 & 0.00 & 0.00 & 0.00 \\
\hline 39 & -0.86 & 0.00 & 0.00 & 0.00 & 0.00 & 0.00 \\
\hline 40 & 0.00 & 0.78 & 0.00 & 0.00 & 0.00 & 0.00 \\
\hline 41 & -0.69 & 0.66 & 0.00 & 0.00 & 0.00 & 0.00 \\
\hline 42 & 0.00 & 0.00 & 0.60 & 0.00 & 0.00 & 0.47 \\
\hline 43 & 0.00 & 0.00 & 0.00 & 0.00 & 0.00 & 0.53 \\
\hline 44 & 0.00 & 0.54 & 0.49 & 0.00 & 0.00 & 0.00 \\
\hline 45 & 0.00 & 0.58 & 0.65 & 0.00 & 0.00 & 0.00 \\
\hline
\end{tabular}

3 визначених недоліків логічно випливають і напрями подальшого розвитку методичного апарату для порівняльного оцінювання бойової могутності $3 \mathrm{C}$ різних країн світу, а саме:

визначення переліку показників, 3 використанням яких доцільно оцінювати бойову могутність різних армій;

удосконалення методики порівняльного оцінювання бойової могутності збройних сил різних країн світу 3 метою усунення виявлених недоліків;

використання методів кластеризації для розподілу ЗС країн світу на однорідні групи (за деякими ознаками), в межах яких і доцільно здійснювати порівняння їх бойової могутності.

Висновки та перспективи подальших досліджень. Таким чином, у статті 3 використанням апарату факторного аналізу проведено аналіз існуючого методичного апарату для порівняння бойової могутності 3С різних країн світу. На конкретних прикладах показані проблеми, пов'язані зі змістовною інтерпретацією отримуваних за ним результатів.

Подальший розвиток проведених досліджень вбачається в практичній реалізації напрямів розвитку методичного апарату для 
порівняльного оцінювання бойової могутності 3С різних країн світу.

\section{СПИСОК ВИКОРИСТАНОЇ ЛІТЕРАТУРИ}

1. Военный энциклопедический словарь [Текст]. М.: Большая Российская энциклопедия, "РИГТОЛ КЛАССИК”, 2002. - 1664 с.

2. Shen L. RANKED: The strongest militaries in the world [Електронний ресурс]. - Режим доступу http://www.businessinsider.com/ranked-thestrongest- militaries-in-the-world-2015-9.

3. В рейтинге сильнейших армий мира Украина поднялась на 21 место [Электронный ресурс]. Режим доступа - https://rn.t5n.ua/politika/vreytinge- silneyshih-armiy-mira-ukraina-podnyalas- na-21 -mesto-3 77043.html.

4. https://www.globalfirepower.com/countrieslisting.asp.

5. Барковский С. С. Многомерный анализ данных методами прикладной статистики [Текст]: учеб. пособие // С. С. Барковский, В. М. Захаров, А. М. Лукашов, А. Р. Нурутдинова, С. В. Шалагин. - Казань: Изд. КГТУ, 2010,-126 с.

6. Плохотников К. 3. Статистика [Текст] : учеб. пособие / С. В. Колков. - М.: ФЛИНТА, 2012. - 288 c.

7. Дьячук A. А. Математические методы в психологических и педагогических исследованиях [Текст]: учеб. пособие / Красноярск: Красноярский гос. пед. ун-т им. В. П. Астафьева, 2013. - 347 с.

Стаття надійшла до редакції 26.10.2017

Хомчак Р. Б.

Министерство обороны Украины, Киев

Анализ методического аппарата для сравнительной оценки боевой мощи вооруженных сил разных стран мира и направления его дальнейшего развития

Резюме. В статье проведен анализ современного методического аппарата для сравнительной оценки боевой мощи вооруженных сил разных стран мира с использованием факторного анализа и определены направления его дальнейшего развития.

Ключевые слова: сравнительная оценка, факторный анализ, рейтинг вооруженных сил, боевая мощь вооруженных сил.

\section{R. Homchuk}

Ministry of Defense of Ukraine, Kiev

An analysis of the methodological apparatus for a comparative evaluation of the combat power of the armed forces of different countries of the world and the direction of its further development

Resume. The article analyzes the modern methodological apparatus for comparative evaluation of the combat power of the armed forces of different countries of the world using factor analysis and determines the directions for its further development.

Keywords: comparative assessment, factor analysis, the rating of the armed forces, the combat power of the armed forces. 